\title{
Communication
}

[Comunicação]

\section{HER-2 gene expression in atypical ductal hyperplasia associated with canine mammary carcinomas}

\author{
[Expressão gênica de HER2 em hiperplasias ductais atípicas associadas \\ a carcinomas mamários caninos]
}

\author{
E. Ferreira, A.C. Bertagnolli, H. Gobbi, G.D. Cassali
}

Instituto de Ciências Biológicas - Universidade Federal de Minas Gerais - Belo Horizonte, MG

Different types of non-invasive epithelial mammary lesions are associated to a risk of developing breast cancer in the human and canine species. The process of malignant neoplasm progression is observed in canine mammary tumors, where the development of carcinomatous foci (carcinomas in situ) may result in the formation of invasive carcinomas associated to these tumors (Bertagnolli et al., 2009; Mouser et al., 1999).

Cytogenetic evaluations of canine mammary tumors have shown that the chromosomal region 1q13.1, where the HER2 gene is located in this species, is very affected by chromosomal aberrations (Murua et al., 2001). Studies of chromogenic in situ hybridization (CISH) in different mammary dysplasias and neoplasms have not shown any relation between the overexpression of HER2 and the gene amplification of HER2 in canine mammary cancer (de las Mulas, 2003). Nevertheless, the purpose of the change in molecular behavior regarding the process of neoplastic progression still remains unclear.

Therefore, in the present work we aim to investigate the relation between the expression of HER2 protein and the HER2 gene status through the chromogenic in situ hybridization technique in HDA associated with canine mammary carcinomas.

Three cases of canine mammary carcinomas were retrieved from the files of the Laboratory of Comparative Pathology, Institute of Biological

Recebido em 21 de setembro de 2012

Aceito em 12 de dezembro de 2013

E-mail: enioferreira@icb.ufmg.br
Science, Federal University of Minas Gerais, Brazil. The selection was based on histopathological diagnosis according to the World Health Organization criteria (Misdorp et al., 1999). All procedures were performed following the guidelines of the Ethics Committee in Animal Experimentation.

All tissue samples were previously fixed in $10 \%$ neutral formalin and embedded in paraffin. Paraffin blocks were selected and consecutive 3 $\mu \mathrm{m}$ thick sections were obtained and mounted on silanized slides for an immunohistochemical study. Primary antibody monoclonal rabbit antihuman HER2 Oncoprotein (c-erbB-2; 1:100 ${ }^{\mathrm{a}}$ ) was incubated overnight (16-18hs) at $8^{\circ} \mathrm{C}$. After incubation, immunodetection was performed with the technology to prepare polymeric HRP-linker antibody, with diaminobenzidine chromogen as substrate ${ }^{\mathrm{a}}$. As a positive control slide we used human and canine mammary cancer tissue known to express the antibodies. Negative controls were evaluated using normal serum as the primary antibody. HER 2 expression was defined as epithelial cell membrane staining and scored according to the American Society of Clinical Oncology (Wolff et al., 2007).

CISH was performed using the double-stranded DNA HER2 probe ${ }^{c}$ according to the manufacturer's instructions and was evaluated with the kit interpretation guidelines. At least 30 non-equivocal and non-overlapping neoplastic cells were counted per case. The probe displays a single distinct small dark brown sign at the location of each copy of the HER2 gene and the number of signs was counted in malignant 
mammary epithelial cells only using a quantitative method. Signs were evaluated at $600 \times$ and non-equivocal signs were counted. The expected number of signs in a normal and in an unamplified tumor cell varies from two to five signs per nucleus in $>50 \%$ of tumor cells, depending on the phase of the cell cycle, and was classified as non-amplified. Precise sign enumeration was not possible in some sections because tumors with high levels of gene amplification often exhibit coalescing sign clusters. Thus, amplification was defined as more than five signs per nucleus or when gene copy clusters were seen in $>50 \%$ of cancer cells.

The primary purpose of this part of the study was defined as mammary gland containing synchronous $\mathrm{ADH}$ in analyses of canine mammary carcinomas. For the histological classification, all three cases of invasive carcinomas were classified as carcinomas in benign mixed tumors. The malignant component is characterized by infiltrative growth, cell pleomorphism and abnormal mitoses. ADH projections were usually characterized by solid to papillary proliferations of small, dark, cuboidal to low columnar cells, often forming parallel rows with a palisading or basaloid cell appearance.

Immunohistochemical overexpression of HER2 protein (3+) was clearly present in all three canine mammary carcinomas (Figure 1A). Normal and ADH occurred in the same mammary gland, and all proved to be negative for HER2 $(2+, 1+, 0)$ protein expression (Figure 1B). Cytoplasmic staining for HER2 was found in the normal mammary epithelial cells, but not in $\mathrm{ADH}$

Criteria for successful CISH analysis included identifying at least one copy of the HER2 gene per nucleus in most cancer cells. CISH was successful in all three cases, however, all invasive carcinomas and associated ADH had an overexpression of the protein but had no gene amplification, showing typically one to two dots per nucleus (Figures 1B and 1C).
The HER2 overexpression, which correlates with a more rapid progression and a worse prognosis in canine mammary cancer, suggests a possible role in carcinogenesis and works as a prognostic indicator (Dutra et al., 2004).

HER2 gene amplification, in humans, occurs in approximately $20 \%$ human breast cancer patients (Wolff et al., 2007). Thus, a model of mammary carcinogenesis with pathological similarities to those in humans is needed and different authors have reported the use of female dogs for prognostic and predictive evaluation of the cancer (Uva et al., 2009).

In the invasive canine mammary cancer studied, HER2 gene amplification was not evident. Previous studies have demonstrated that human metaplastic breast carcinomas, a histological subtype with histological similarities to canine mixed tumors, with a lack of HER2 overexpression, but HER2 gene amplification was not observed (Reis-Filho et al., 2005). This fact can also be observed in other human tumors, approximately $2 \%$ of breast cancer patients express discordant HER2 protein expression independently of the HER2 gene amplification (Powe et al., 2009). HER2 transcription in the absence of gene amplification may be related to the mechanism of cell function through the enhanced production of mRNA by phosphorylation of tyrosine kinase acting on growth factors and regulators of cell growth and proliferation (Murua et al., 2001).

In contrast to canine mammary cancer, the analyses of ADH presented here have not revealed the presence of HER2 protein alterations. Thus, similarly, the absence of HER2 amplification was observed in these cases. The practical importance of intraepithelial canine mammary studies is related to their potential for malignant transformation and the absence of alterations indicates that this gene may not be involved in the initial stages of proliferation. 


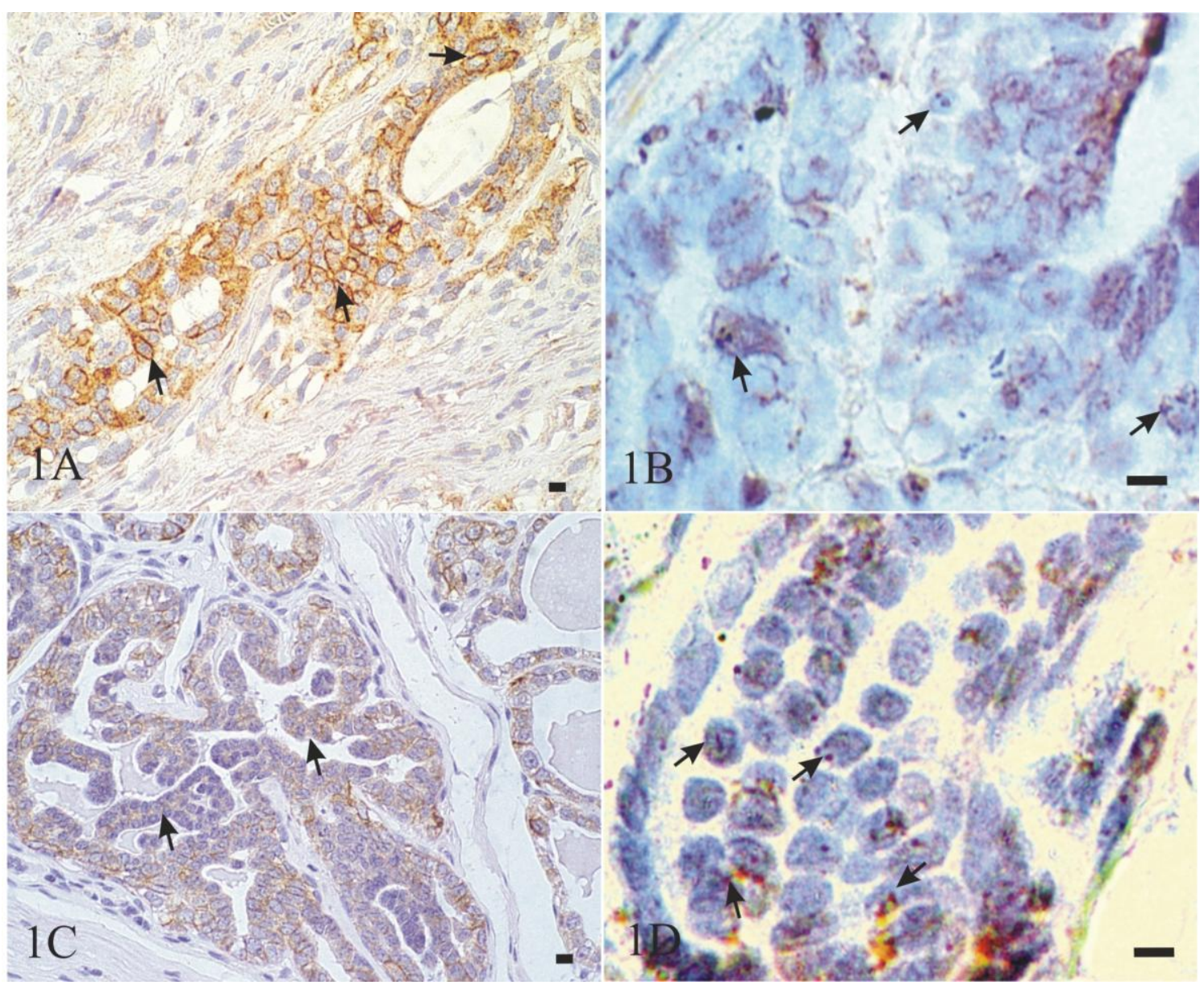

Figure 1: Canine mammary gland. 1A) Carcinoma in a benign mixed tumor, 600x; Immunohistochemistry: malignant epithelial component shows intense membrane staining for HER2 in more than $30 \%$ of tumor cells (3+ score); 1B) Carcinoma in a benign mixed tumor, 1000X; Chromogenic in situ hybridization: HER-2 oncogene copies in invasive mammary carcinoma cells. One or two brown dots per nucleus are seen in both malignant epithelial cells (arrows); 1C) Atypical ductal hyperplasia, 600x; Immunohistochemistry: atypical ductal hyperplasia showing negative membrane expression of HER2 in epithelial cells; 1D) Atypical ductal hyperplasia; 1000X; Chromogenic in situ hybridization: the normal HER2 gene appears as one or two gene copies in atypical ductal cells hyperplasia (arrows). Bar = $10 \mu \mathrm{m}$.

The use of the canine species may be the most appropriate model for progression to invasive breast cancer studies due to the oncogenic similarities of human mammary lesions. However, further research will be necessary to verify the usefulness of these markers as tools for the evaluation of the malignant potential of benign mammary tissue.

Keywords: birds, embryonic development, hatchability, prestorage

\section{RESUMO}

O presente estudo apresenta o comportamento do gene HER2, a partir do uso da técnica de hibridização cromogênica in situ, em hiperplasias ductais atípicas associadas a carcinomas mamários caninos positivos para HER2. Aparentemente, uma fraca expressão da proteína HER2 foi observada nas hiperplasias ductais atípicas, bem como uma ausência de amplificação do seu gene codificador nessas hiperplasias e nos carcinomas mamários associados. O comportamento da proteína HER2 e do seu gene 
em carcinomas mamários caninos é similar ao observado em alguns subtipos histológicos de tumores mamários humanos, e a ausência dessas alterações sugerem que esse gene poderia aparentemente não estar envolvido com os estágios iniciais de proliferação celular atípica.

Palavras-chave: caninos, neoplasia mamária, imuno-histoquímica, hibridização cromogênica in situ

\section{ACKNOWLEDGEMENTS}

The authors thank the National Council of Scientific and Technological Development (CNPq; Brazil), and the Research Support Foundation of the State of Minas Gerais (FAPEMIG; Brazil) for financial support.

\section{REFERENCES}

BERTAGNOLLI, A.C.; CASSALI, G.D.; GENELHU M.C.L.S. et al. Immunohistochemical expression of p63 and $\Delta$ np63 in mixed tumors of canine mammary glands and its relation with p53 expression. Vet. Pathol., v.46, p.407-415, 2009.

De las MULAS, J.M.; ORDÁS, J.; MILLÁN, Y. et al. Oncogene HER-2 in canine mammary gland carcinomas: An immunohistochemical and chromogenic in situ hybridization study. Breast Cancer Res. Treat., v.80, p.363-367, 2003.

DUTRA, A.P.; GRANJA, N.V.; SCHMITT, F.C.; CASSALI, G.D. C-erbB-2 expression and nuclear pleomorphism in canine mammary tumors. Braz. J. Med. Biol. Res., v.37, p.1673-81, 2004.

MISDORP, W.; ELSE, R.W.; HELLMÉN, E.; LIPSCOMB, T.P. Histological classification of mammary tumors of the dog and the cat. 2nd series, vol VII, Washington DC.: AFIP, 1999. p.1-59.

MOUSER, P.; MILLER, M.A.; ANTUOFERMO, E. et al. Prevalence and classification of spontaneous mammary intraepithelial lesions in dogs without clinical mammary disease. Vet. Pathol., v. 47, p.275-84, 2010.
MURUA ESCOBAR, H.; BECKER, K.; BULLERDIEK J.; NOLTE, I. The canine ERBB2 gene maps to a chromosome region frequently affected by aberrations in tumors of the dog (Canis familiaris). Cytogenet. Cell Genet., v.94, p.194-195, 2001.

POWE, D.G.; AKHTAR, G.; HABASHY, H.O. et al. Investigating $\mathrm{AP}-2$ and $\mathrm{YY} 1$ protein expression as a cause of high HER2 gene transcription in breast cancers with discordant HER2 gene amplification. Breast Cancer Res., v.11, p.R90, 2009.

REIS-FILHO, J.S.; MILANEZI, F.; CARVALHO, S. et al. Metaplastic breast carcinomas exhibit EGFR, but not HER2, gene amplification and overexpression: immunohistochemical and chromogenic in situ hybridization analysis. Breast Cancer Res., v.7, p.1028-1035, 2005.

UVA, P.; AURISICCHIO, L.; WATTERS, J. et al. Comparative expression pathway analysis of human and canine mammary tumors. BMC Genomics, v.27, p.135, 2009.

WOLFF, A.C.; HAMMOND, M.E.; SCHWARTZ, J.N. et al. American Society of Clinical Oncology/College of American Pathologists Guideline Recommendations for Human Epidermal Growth Factor Receptor 2 Testing in Breast Cancer. Arch. Pathol. Lab. Med., v.131, p.18, 2007. 